\title{
METAPHORS USED TO COMMUNICATE THE CORONAVIRUS STATE OF EMERGENCY IN THE UNITED KINGDOM AND SPAIN: A CONTRASTIVE ANALYSIS
}

\author{
LAS METÁFORAS UTILIZADAS \\ EN LA DECLARACIÓN DEL ESTADO DE ALARMA \\ POR CORONAVIRUS EN EL REINO UNIDO \\ Y ESPAÑA: UN ANÁLISIS CONTRASTIVO
}

\author{
ELIECER CRESPO-FERNÁNDEZ \\ Universidad de Castilla-La Mancha \\ eliecer.crespo@uclm.es
}

\begin{abstract}
Since it emerged in China at the beginning of 2020, the COVID-19 virus has spread to almost every country in the world. In response to the health and economic crisis triggered by the pandemic, political legislators were forced to declare a state of national emergency in an effort to stem the spread of the coronavirus. Following a critical discourse approach to metaphor analysis, this study examines the metaphors employed by the British and Spanish Prime Ministers in their declarations of the state of emergency. The results support the view that metaphor is a double-edged sword in times of crisis: it is not only used to help people to face the coronavirus pandemic, to instil courage and hope; it also serves as a strategy of positive self-presentation whereby political actors try hard to avoid criticism and gain the approval of public opinion.
\end{abstract}

Keywords: political rhetoric, critical discourse studies, critical metaphor analysis, cognitive theory, coronavirus pandemic.

\section{Resumen}

Desde que surgió en China al principio del 2020, el coronavirus se ha extendido prácticamente a todos los países del mundo. En respuesta a la crisis económica y 
sanitaria motivada por la pandemia, las autoridades se vieron obligadas a declarar el estado de alarma en un intento de frenar la expansión del virus. Siguiendo un enfoque crítico-discursivo al análisis de la metáfora, este trabajo examina las metáforas utilizadas por los presidentes de los gobiernos británico y español en sus declaraciones oficiales del estado de alarma. Los resultados obtenidos revelan que la metáfora es un arma de doble filo en situaciones de crisis: no solo se utiliza para ayudar a los ciudadanos a afrontar la pandemia y transmitir un mensaje de esperanza; también está al servicio del político para intentar evitar la crítica y ganar apoyo entre la opinión pública.

Palabras clave: retórica política, estudios críticos del discurso, análisis crítico de la metáfora, semántica cognitiva, coronavirus.

\section{Introduction}

Since it emerged in China at the beginning of 2020, the coronavirus (officially named COVID-19) has spread to almost every country in the world, resulting in an unparalleled health, social and economic crisis which has seriously hit many European countries such as the United Kingdom and Spain, on which the present study is based. Although it was considered, maybe for too long, that the threat of COVID-19 was manageable and would never go so far as to bring about the collapse of national health services, the fact remains that the coronavirus has proved to be a terrifying enemy, more infectious and lethal than initially thought.

In response to the health and economic crisis triggered by the pandemic, political legislators were forced to declare a state of national emergency in an effort to stem the spread of coronavirus by locking down parts of the economy and implementing strict social distancing guidelines. In this period of unprecedented disruption, the British and Spanish Prime Ministers, Boris Johnson and Pedro Sánchez, were in charge of communicating the declaration of the state of emergency caused by the coronavirus outbreak. Needless to say, the way politicians communicated the lockdown decision is of vital importance, not only for the population at large, but also for the image of the political leaders and that of the parties they represent. We should not forget that the primary motivation for political communication is, following Fairclough (1989: 189), strategic, i.e. it is intended to reach certain instrumental goals whose attainment is expected to benefit those responsible for producing the message. In this sense, the language skills politicians display and the words they choose are key factors for generating support for their position and influencing people's thoughts. 


\section{Metaphors Used to Communicate the Coronavirus State of Emergency}

Drawing from the theoretical paradigm of Critical Metaphor Analysis, the objective of the present study is to examine the metaphors used by the British and Spanish Prime Ministers in their official declarations of the state of emergency for COVID-19 and to gain an insight into their affective and persuasive effects. I depart from the basic assumption that metaphors are vital to the language of political leadership and essential tools for persuasion and seduction in the public sphere. This study adds to the already existing research about the role of metaphors in talking about coronavirus in different discourse types and genres (Craig 2020; Fernández-Pedemonte et al. 2020; Wicke and Bolognesi 2020; Semino 2021; Pérez-Sobrino et al. in press). From a more general perspective, it can be included within research on metaphor and disease (Trčková 2015; Balteiro 2017), research on human action against adversity (Karlberg and Buell 2005) and research on metaphor and political rhetoric (Charteris-Black 2004, 2005; Ferrari 2007; Musolff 2016).

The declarations of the state of emergency have been chosen as the source of data because these texts are good examples of persuasive political communication in which every element is carefully chosen to shape belief, mold attitudes and inspire confidence in difficult times for the population. More specifically, the public declarations which constitute the corpus data for this research are examples of effective subsumed propaganda, i.e. that related to value systems underlying the language which are taken for granted in the ideology of a community (Hughes 1998: 206-208). The choice of Johnson and Sánchez is not random, either. Their speeches are representative examples of the way political leaders use words not only to inform, but also to protect their public image, which seems particularly necessary in speeches in which they are asking their citizens to follow strict rules and make sacrifices for a common good.

This paper is organised as follows. After presenting the theoretical paradigms on which this study relies, it goes on to present the corpus and describe the research methodology employed to examine the language data. It then proceeds to the analysis and discussion of the role of metaphor in the declarations consulted, which constitutes the core of this paper. Some concluding remarks and suggestions for further research bring the study to an end.

\section{Theoretical Framework}

As contemporary metaphor theory (Lakoff 1993; Lakoff and Johnson 1999) seems to be too limiting to account for the communicative potential of figurative language in public discourse, ${ }^{1}$ the theoretical assumptions on which this study relies derive from a more comprehensive and socially-oriented approach to 
metaphor: Charteris-Black's $(2004,2005,2014)$ Critical Metaphor Analysis (henceforth CMA), a politically oriented analytical framework drawing on the insights of Critical Discourse Analysis and Cognitive Linguistics. As a cognitivelybased approach, CMA assumes that metaphor is a cognitive device with the capacity to structure our conceptual system and provide a particular understanding of the world through the correspondence between the linguistic content of metaphors (i.e. source domain) and what they describe (i.e. target domain). This view of metaphor as a cross-domain conceptual mapping provides for two levels of metaphor, which basically correspond to Lakoff's (1993) concepts of "metaphor" and "metaphorical expression": conceptual metaphor, i.e. a semantic mapping that takes the form of target domain/source domain, and linguistic metaphor, i.e. the surface realisations of the cross-domain mappings. In the cognitive tradition, metaphors have been classified according to criteria that profile the different aspects of the conceptual operation. ${ }^{2}$

Charteris-Black assumes that metaphor is a cross-domain mapping in conceptual structure but goes beyond Lakoff's approach to metaphor in that he argues that the application of cognitive theory to metaphor use can provide "particular insights into why the rhetoric of political leaders is successful" (2005: 197). In this respect, the linguistic metaphors used in political discourse are not only conceived as a matter of language but also, and more importantly, as a matter of thought which have a communicative impact and serve a particular rhetorical purpose in persuasive genres such as political speeches. This is in line with Steen's three-dimensional model of metaphor, according to which "metaphor may be theoretically defined as a matter of conceptual structure, but in empirical practice it works its wonders in language, communication, or thought" (2011: 59). Charteris-Black relates critical aspects of language use with cognitive assumptions so as to "identify which metaphors are chosen in persuasive genres such as political speeches, party political manifestos or press reports, and attempts to explain why these metaphors are chosen" (2014: 174).

The analysis of the conscious use of metaphor as a persuasive strategy is key in Charteris-Black's framework. This author proposes the notion of purposeful metaphor in order to explain the intended effect of metaphor within a "theory of metaphor in communication where there is linguistic and contextual evidence of purpose" (2012: 2). Indeed, the adoption of a discourse perspective necessarily leads to interpreting metaphor use with reference to its intended outcome "which involves considerations of authorship, audience, occasion of language use and — significantly - communicative purpose" (2012: 3). In this way, CharterisBlack's approach to metaphor, closely related to Steen's (2015) notion of deliberate metaphor, allows gaining an insight into the deliberate use and rhetorical impact 
of figurative language in political communication. ${ }^{3}$ We should not forget that political speeches are purpose-oriented and carefully constructed with persuasive goals in mind. In this context, not only are novel metaphors consciously and strategically used; conventional metaphors may also be intentional and have a relevant function in argumentative discourse (van Poppel 2020).

\section{Corpus and Methodology}

The corpus for the present research consists of the official declarations of the states of emergency delivered by the British Prime Minister, Boris Johnson, on March 23, 2020 and by the President of the Spanish Government, Pedro Sánchez, on March 14,2020 . The transcriptions of both declarations are freely available on the websites of the British government (www.gov.uk/government/speeches/pm-address-tothe-nation-on-coronavirus-23-march-2020) and the Spanish government (www. lamoncloa.gob.es/presidente/intervenciones/Paginas/2020 prspl4032020.aspx). The sample amounts to a total of 4,129 words in which 72 metaphorical words and expressions have been encountered, which are distributed as follows: 898 words and 25 metaphorical items are found in the British subcorpus whereas the Spanish one comprises 3,231 words out of which 47 are used metaphorically.

It is important to note that the study presented here can make no claim to completeness. Although I have relied on a set of limited data samples in the tradition of discourse analysts (see, for example, Charteris-Black 2005; Ferrari 2007; Negro 2011), essential principles of data compilation such as representativeness of the sample and thematic homogeneity (Caballero and Ibarretxe-Antuñano 2009) are guaranteed. Indeed, the analysis of the corpus demonstrates that the research issue (metaphor in this case) is used in institutional communication at times of national crisis.

The research method used to examine the data corresponds to the adoption of an inductive, "bottom-up" approach: I started from the linguistic data and explored the functions that metaphor performs in the declarations of the state of emergency. To this end, I followed the three stages in metaphor analysis -identification, interpretation and explanation- proposed by Charteris-Black (2014): first, I selected metaphorical items (be they words or expressions) from the corpus; second, I assigned the metaphorical units encountered in the sample to their corresponding conceptual networks; and third, I explained the ideological intentions underlying the metaphor use. Since the subcorpora are of unequal size (the Spanish subcorpus is considerably larger), I did not only calculate the absolute, or raw, frequency of occurrence of each metaphorical item used to talk about the pandemic; I also calculated the relative, or normalised, frequency, i.e. the absolute 


\section{Eliecer Crespo-Fernández}

frequency divided by the total number of items contained in each corpus, of the classified metaphorical occurrences encountered in both data sets. In order to standardise the results, the relative frequency was calculated per 1,000 words, following the convention for normalising the frequency scores in small corpora (cf. Anderson and Corbett 2017).

As metaphors are not always easy to identify in natural discourse, I relied on the Metaphor Identification Procedure (MIP), a method for metaphor detection developed by the Pragglejaz Group (2007). This procedure consists of the following steps: first, establishing the meaning of the lexical unit in the context in which it appears; second, determining the more basic contemporary meaning that the word in question has; and third, deciding whether the contextual meaning of the examined word contrasts with a more basic, contemporary meaning but can be understood in comparison with it. If this happens, the word is taken to be metaphorical. Let us take the term enlisted ("every one of us is directly enlisted") as an example of how this procedure has been applied. The contextual meaning of enlisted ('people who are ready to fight against the virus') contrasts with its basic meaning ('people who have joined the armed forces') but can be understood by some sort of familiarity with it (people are seen as soldiers). Therefore, enlisted is a word used metaphorically in that context.

\section{Results and Discussion}

A variety of conceptual metaphors used by the national leaders of both countries were identified in the sample. As mentioned above, a total of 72 metaphorical units were encountered, divided as follows: the British subcorpus contains 25 metaphorical items whereas the Spanish one comprises 47 words and expressions that are metaphorically used. The results concerning the relative frequency of occurrence of metaphor show that there is a considerably higher density of metaphor use in the British declaration of the state of emergency (27.83) than in the Spanish (14.54). I will now consider the absolute and relative frequency of metaphorical items in both subcorpora classified by source domain.

In the British subcorpus, the metaphorical units fall under six source domains/ concepts. ${ }^{4}$ The source domains are, in quantitative order: WAR $(n=10)$, PERSON $(n=6)$, HERo $(n=4)$, JOURNEY $(n=3)$ and NATURAL PHENOMENA $(n=1)$, and the source concept is VERTICALITY $(\mathrm{n}=\mathrm{l})$. As far as the Spanish subcorpus is concerned, the metaphorical items encountered can be assigned to five metaphors, namely those which take WAR $(\mathrm{n}=18)$, PERSON $(\mathrm{n}=15)$, HERO $(\mathrm{n}=6)$ and JOURNEY $(\mathrm{n}=6)$ as source domains, and VERTICALITY $(\mathrm{n}=2)$ as concept. The raw frequency of linguistic metaphors in the corpus classified by source domain/concept is graphically shown in Figure 1: 


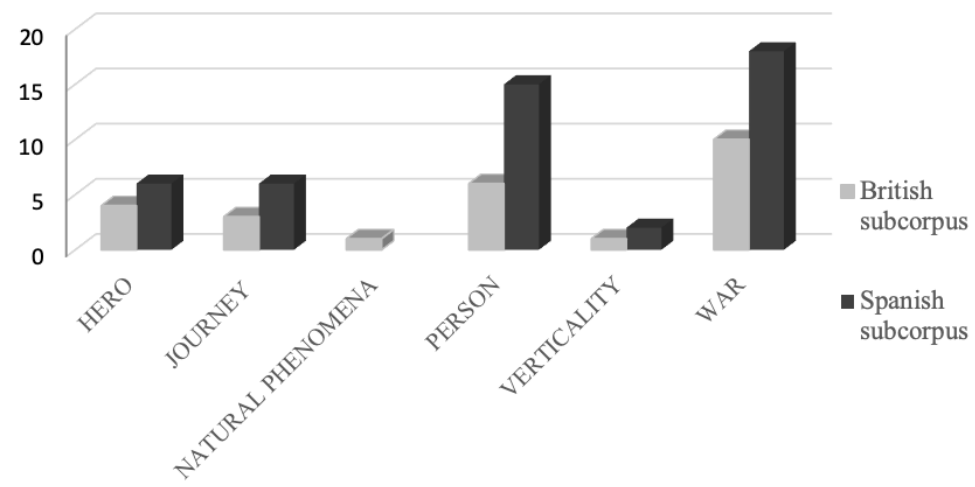

Figure 1. Absolute frequency of metaphorical expressions by source domain/concept in both subcorpora

It is worth noting that the set of source domains/concepts used by the political leaders of both countries is identical with the exception of NATURAL PHENOMENA, which is absent in the Spanish subcorpus. Concerning absolute frequency, it was found that WAR and PERSON rank as the most frequent domains, followed, at a distance, by HERO and JOURNEY. The remaining source domains/concepts (NATURAL PHENOMENA and VERTICALITY) have little relevance in quantitative terms.

The relative frequency of each source domain or concept in both subcorpora can be seen in Figure 2.

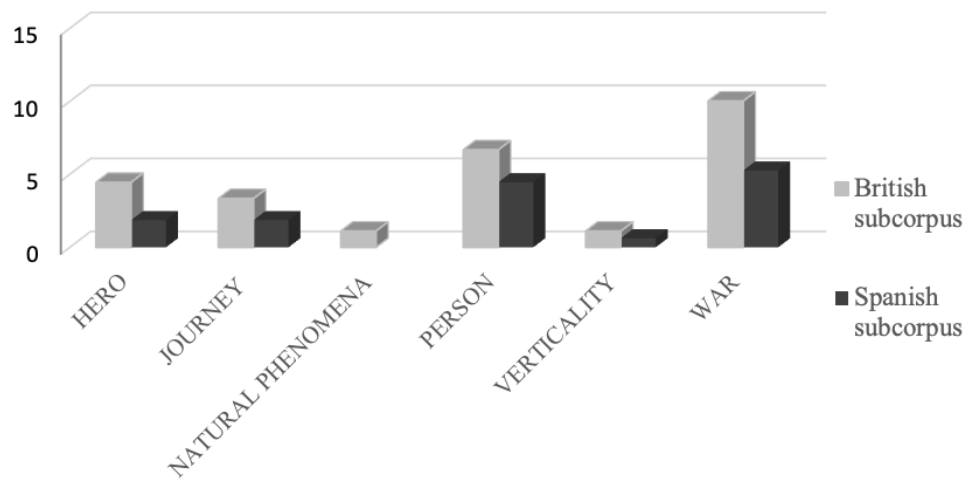

Figure 2. Relative frequency of source domains/concepts in both subcorpora 
In accordance with the higher density of metaphor use in Johnson's declaration, the frequency of usage of the shared source domains is more relevant in the British subcorpus than in the Spanish. This is especially evident in the domains that have a higher frequency in both subcorpora such as WAR ( 11.13 vs 5.57$)$, PERSON (6.68 vs 4.64 ), HERo (4.45 vs 1.86 ) and JOURNey ( 3.34 vs 1.86 ). The source domains/ concepts that are not quantitatively relevant also follow this pattern: vERTICALITY ( 1.11 vs 0.62 ) and NatUral PHENOMENa ( 1.11 vs 0 ).

The target domains that have been identified are the same in both data sets: RECOVERY,

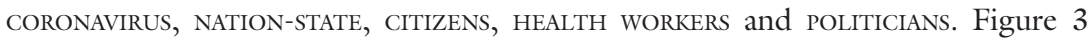
shows the relative frequency in which these six domains appear in the sample:

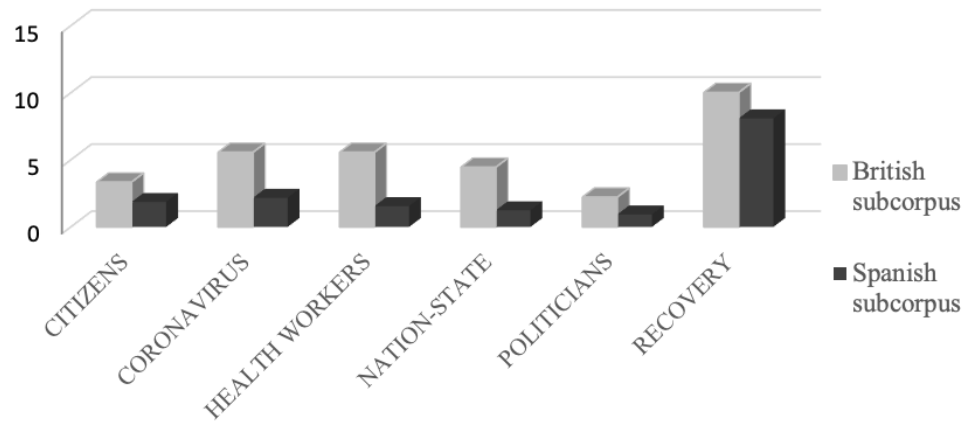

Figure 3. Relative frequency of target domains in both subcorpora

In both subcorpora, RECOVERY is the target domain which has the highest occurrence, and the only one with a similar normalised frequency rate (10.02 vs 8.09 ). The metaphorical references to the process of recovery from the disease are followed, at a distance, by those that evoke the coronavirus itself ( 5.56 vs 2.17 ) and health workers (5.56 vs 1.55 ). To a lesser extent, Johnson and Sánchez talk about the state ( 4.45 vs 1.24$)$, citizens (3.34 vs 1.86$)$ and politicians $(2.22$ vs 0.93 ) in metaphorical terms.

I will turn now to comparing the way metaphors are used by the British and Spanish national leaders to address the coronavirus pandemic.

\subsection{The WAR Metaphor}

The WAR domain is the most common source of metaphorical items both in absolute and relative terms (cf. Figures $\mathrm{l}$ and 2), which seems to confirm the pervasiveness of WAR metaphors to refer to human action against diseases such as 
COVID-19 (Craig 2020; Wicke and Bolognesi 2020; Semino 2021) or Ebola (Trčková 2015; Balteiro 2017). The major theme of this metaphor or main meaning focus, i.e. "the basic and central knowledge about the source domain, inherited by the target, that is widely shared in a community" (Kövecses 2005: 12), is violence, which leads to the reinterpretation of the measures taken against the disease as inherently hostile and aggressive. War-related words and expressions belong to a conceptual metaphor that can be formulated as CORONAVIRUS IS WAR or, more precisely, RECOVERING FROM CORONAVIRUS IS FIGHTING IN WAR, a resemblance metaphor (Grady 1999) that arises from a behavioural comparison between source and target (i.e. the source and target domains share some features which motivate the metaphorical mapping), ${ }^{5}$ and a "many-correspondence" metaphor (Ruiz de Mendoza Ibáñez 1997), as such shared features are capable of giving rise to multiple meaning implications. In fact, this metaphor presents different sets of ontological correspondences as a result of transferring attributes from the source domain of WAR to talk about the coronavirus disease: to stay healthy is to fight a battle, to overcome the virus is to beat an enemy, to recover health is a victory, the actions against the virus are part of a military mission, citizens are soldiers and the coronavirus is a threat. In Table 1 these conceptual mappings are matched with their corresponding instantiations:

\begin{tabular}{|c|c|c|}
\hline \multirow{2}{*}{$\begin{array}{l}\text { Conceptual } \\
\text { mappings }\end{array}$} & \multicolumn{2}{|c|}{ Instantiation(s) } \\
\hline & British subcorpus & Spanish subcorpus \\
\hline $\begin{array}{l}\text { to stay healthy is } \\
\text { to fight a battle }\end{array}$ & fight the virus & $\begin{array}{c}\text { combatir la propagación del } \\
\text { virus }\end{array}$ \\
\hline $\begin{array}{l}\text { to overcome the } \\
\text { virus is to beat an } \\
\text { enemy }\end{array}$ & $\begin{array}{l}\text { beat the virus } \\
\text { beat the coronavirus }\end{array}$ & $\begin{array}{c}\text { ganar al virus } \\
\text { vencer al virus } \\
\text { ganar la batalla }\end{array}$ \\
\hline $\begin{array}{l}\text { to recover health is } \\
\text { a victory }\end{array}$ & & victoria \\
\hline $\begin{array}{l}\text { actions against the } \\
\text { virus are part of a } \\
\text { military mission }\end{array}$ & & misión \\
\hline $\begin{array}{l}\text { citizens are } \\
\text { soldiers }\end{array}$ & $\begin{array}{l}\text { be enlisted } \\
\text { serve on the frontline }\end{array}$ & \\
\hline $\begin{array}{l}\text { the coronavirus is } \\
\text { a threat }\end{array}$ & threat & amenaza de lo desconocido \\
\hline
\end{tabular}

Table 1. Conceptual mappings and corresponding instantiations in the metaphor CORONAVIRUS IS WAR

As the virus is represented as an enemy in the military rhetoric of both national leaders, the steps that must be taken to stay healthy are represented as a battle 


\section{Eliecer Crespo-Fernández}

against that enemy. In this regard, the process of recovering health, social wellbeing and economic stability is conceptualised as a violent struggle for survival in which citizens and politicians have a mission to accomplish for the welfare of society. This scenario is linguistically manifested in both subcorpora through military terms which focus on the action of fighting such as fight in example (1) and combatir ('fight') in (2):

(1) Tonight I want to update you on the latest steps we are taking to fight the disease and what you can do to help. ${ }^{6}$

(2) Usaremos todos los recursos a nuestro alcance ante una urgencia que nos concierne a todos: combatir la propagación del virus.

(We will use all the resources at our disposal in the face of an emergency that affects us all: to fight against the spread of the virus).

Other war-related expressions emphasise the defeat of the enemy: beat the virus, beat the coronavirus - together with their equivalents in the Spanish subcorpus, ganar al virus and vencer al virus ('beat the virus') - and ganar la batalla ('win the battle'). In the two quotations that follow, both Johnson and Sánchez employ two rhetorical devices to add emphasis: syntactic parallelism and lexical repetition of key words such as beat in (3) and unidos ('united') in (4):

(3) We will beat the coronavirus and we will beat it together.

(4) Unidos, saldremos adelante. Unidos, venceremos al virus.

(United, we will move forward. United, we will beat the virus).

If recovering health is a fight, the endpoint of the recovery period is metaphorically construed as a victory. Significantly enough, the term victoria ('victory') occurs five times in the Spanish subcorpus whereas it does not appear in the British. By way of repetition, Sánchez tries to sound convincing and reassuring about the recovery. Victoria is therefore a key word in Sánchez's address to the nation, a word that carries a strong positive connotation and serves his purpose to inspire confidence in the government's ability to deal with the virus. Here is an example:

(5) La victoria será total cuando $[\ldots]$ contemos con una vacuna que evite futuras pandemias.

(The victory will be complete when $[\ldots]$ we have a vaccine that prevents future pandemics).

As part of Sanchez's warfare rhetoric, everyone is involved in a mission. The WAR metaphor in (6) assumes that the presidents of the Spanish regions are soldiers on a mission; therefore, it is their duty to obey the orders of their superiors, i.e. of the central government authorities: 


\section{Metaphors Used to Communicate the Coronavirus State of Emergency}

(6) Todos y cada uno de los presidentes deberán [...] centrarse en una única misión: entre todas y todos vencer al virus.

(Each and every president will have to focus on just one mission: beat the virus all together).

Johnson goes further in the exploitation of the WAR domain in (7). By virtue of a metaphor that can be formulated as CITIZENS ARE SOLDIERS, also implicitly present in (6), British workers are enlisted and serving on the frontline, directly facing the enemy line:

(7) Everyone from the supermarket staff to the transport workers to the carers to the nurses and doctors on the frontline $[\ldots]$ each and every one of us is directly enlisted.

The representation of essential workers as frontline soldiers highlights the importance of these workers to the nation's well-being. In this respect, Craig argues that "'covid-ian' military metaphors marshal us to valorize 'front-line workers' - those deemed essential to the medical, economic, social, and of course, political establishment"(2020: 1025). From this viewpoint, the war metaphor has positive implications: it becomes a source of empowerment in which citizens, health workers and politicians are portrayed as fighters against a common enemy. ${ }^{7}$

The representation of citizens as soldiers serving on the frontline necessarily leads to considering the coronavirus as an enemy who must be defeated at all costs. In the public addresses of Johnson and Sánchez analysed here, the disease is specifically represented as a malign force that poses a serious threat to the population. Following Baider and Kopytowska (2017), the representation of the enemy as a threat is a powerful device to conceptualise "the other" — considered the common enemy - in times of social and political crisis. ${ }^{8}$ As there is no treatment for a virus that is potentially life-threatening, the feeling of a dangerous threat projects onto the disease. Indeed, as Sontag argues, "any important disease [...] for which treatment is ineffectual, tends to be awash in significance. Feelings about evil (and I would say, danger and threat) are projected onto the disease"(1978: 58). The feelings Sontag refers to are reflected in the metaphorical language used to refer to COVID-19. Both national leaders represent the virus as an enemy, hence a threat, in both a physical and symbolic sense, with a persuasive aim in mind: to warn people about the danger of infection and, in this way, justify the measures taken by their governments:

(8) No hay nada que dañe más el ánimo de una persona que la amenaza de lo desconocido.

(There is nothing more harmful for a person's mood than the threat of the unknown).

(9) The coronavirus is the biggest threat this country has faced for decades. 


\section{Eliecer Crespo-Fernández}

At a linguistic level, the use of warfare imagery is an effective means to intensify and reinforce the argument that the virus is a serious threat to public health and safety whose defeat is everyone's job. In this way, the war metaphors used by Johnson and Sánchez are intended first, to make people believe that the virus will be finally defeated; and second, to make them aware of the need to respect the measures announced by the government, no matter how strict they are.

\subsection{The PERSON Metaphor}

The PERSON source domain is used to target the coronavirus itself and the nationstate. The Great Chain of Being, a cultural model which places four orders or entities (humans, animals, plants and objects) on a vertical scale, in a hierarchy from humans at the top to physical things at the bottom (Lakoff and Turner 1989: 166-167), is especially useful to understand how the PERSON domain is used in the corpus. When the coronavirus and the nation are conceived of as a person, the metaphor proceeds from a higher source domain to a lower target domain for a different communicative purpose: whereas the personification of the virus acquires negative connotations, that of the state implies a positive evaluation of political actors and institutions. Metaphors based on the Great Chain of Being are cases of ontological metaphors, essentially based on resemblance: they exploit attributes that are perceived to be similar across domains (Ruiz de Mendoza Ibáñez and Pérez Hernández 2011: 169-170).

The PERSON metaphor involves treating the disease as a human being or, more precisely, as a malign creature whose job is to inflict harm on the population. The negative personification of the virus, specifically as an enemy and a killer, follows a long-established political tradition of personifying the enemies of one's country (Charteris-Black 2005). Although both Johnson and Sánchez try to make citizens aware of the need to respect the measures taken by their governments, there are some differences regarding the portrayal of the virus as an enemy in both subcorpora that are important to underline. Consider the following quotations:

(10) All over the world we are seeing the devastating impact of this invisible killer.

(11) Estamos ante nuestro verdadero enemigo, que es el virus y la pandemia. Es un enemigo de todos y todos debemos combatirlo unidos.

(We are facing our true enemy, the virus and the pandemic. It is everyone's enemy and all of us must fight against it together).

In (10) there is a more dramatic version of the PERSON metaphor insofar as the coronavirus, unlike in (11), is not simply conceived of as an enemy. Rather, Johnson represents the virus as a killer, which brings to mind the image of a malevolent power, capable not only of posing a threat to people's health but also 


\section{Metaphors Used to Communicate the Coronavirus State of Emergency}

of causing their death. In this respect, the term killer is what van Dijk referred to as an "alarm word"(2005: 117-118), i.e. an explicit and shocking word which performs a clear function in discourse: to persuade the population into staying at home, as the virus has proven to be lethal to people with pre-existing medical conditions. Here, the danger is therefore structured around the fear of death, not only through metaphor but also through metonymy: killer stands for death by virtue of the high-level metonymy AGENT FOR ACTION; more specifically, what we have in (10) is the double metonymy AGENT FOR ACTION FOR (ASSESSED) RESULT ${ }^{9}$ in which the expected result of the action (death) performed by an explicit agent (killer) remains unexpressed. This metonymy involves a domain expansion/ reduction operation (cf. Ruiz de Mendoza Ibáñez 2021: 218-219): the process is one of expansion from agent to action in the first metonymy and of reduction from action to result in the second; that is, we have a domain expansion and reduction combination in which the matrix domain is the action frame, and the agent (killer) and the result (death) are the subdomains.

The fact that killer is premodifed by the adjective invisible makes the virus more threatening, as people feel unable to fight against an enemy who cannot even be seen. Indeed, because of the primary metaphor, or correlation metaphor in Grady's (1999) terms, KNOWING Is SEEING: what you cannot see lies outside your knowledge and therefore your control of the situation, leaving one helpless in the face of danger. As Kovëcses explains, in this metaphor there is a correlation between two events within the same frame in such a way that one of the events or states (SEEING), i.e. the source domain, gives rise to the target domain (KNOWING) (2013: 81-82). From this perspective, the relationship between seeing and knowing can be considered an experiential correlation within the same primary scene and therefore it can be thought of as metonymic: SEEING SOMETHING PHYSICAL FOR KNOWING THE THING.

There is another version of the PERSON metaphor that acquires positive connotations in the declarations of both leaders: the STATE-AS-PERSON metaphor, deeply ingrained in political thought (Musolff 2016: Ch. 7). The person metaphor is metonymybased: we find a metonymic development of the source domain whereby the country stands for its citizens. The effects of using the personification metaphor in public discourse depend on one's view of what a person is like. A person in both subcorpora is seen as socially cooperative, responsible and helpful, in line with liberal political ideology (Chilton and Lakoff 2005: 40). However, the intended effects of using the PERSON-AS-STATE metaphor are different in each declaration. For Johnson, the United Kingdom is endowed with human abilities such as problem solving and social interaction as a way to emphasise the sense of community and the pursuit of common goals (12), whereas Sánchez personifies the state in order to instil courage in the population (13): 


\section{Eliecer Crespo-Fernández}

(12) The coronavirus is the biggest threat this country has faced for decades —and this country is not alone.

(13) España ha demostrado y está demostrando que tiene capacidad de recuperarse frente a la adversidad.

(Spain has demonstrated its capacity to recover from adversity).

The STATE-AS-PERSON metaphor is the source of a range of metaphorical entailments. If the state is a person at a conceptual level, it has a body which can be healthy, ill, strong, weak and so on. This mapping can therefore be regarded as a special case of embodiment: abstract concepts are referred to in terms of body parts and physiological functions. In addition, this metaphor implies that the country has a particular emotional quality and personality. These entailments of the metaphor are illustrated in (14), in which the notion of strength transmits an optimistic and positive message: Spain will eventually overcome the effects of the coronavirus crisis.

(14) Si de algo estamos convencidos es de la fortaleza de este país.

(If we are sure of something, it is of the strength of our country).

In this example, the term fortaleza ('strength') evokes both a physical and a moral quality: the implication is that Spain, conceptualised as a human body, is not only physically strong, and therefore in good health, despite the effects of the virus; it is also morally strong. This metaphor allows a perception of politicians, and citizens in general, not only as powerful, but also as morally strong and therefore capable of undertaking moral actions; in fact, as Lakoff argued, moral actions attest to strength (1995: 183). In this context, then, the notion of strength not only conveys the idea of power but highlights the moral qualities of citizens and political administrators.

\subsection{The HERO Metaphor}

The Hero (also called HEROIC MYTH) metaphor reinforces the notions of power, solidarity and courage in the face of danger. This metaphor derives from the folk belief that heroes are brave and bold characters whose mission is to fight against malign forces, protect people and save lives. Following Kinsella et al., heroes inspire others to take action, make efforts towards common goals, promote a sense of collectivity and offer hope to those who need it (2019: 482).

In our corpus, the HERO metaphor portrays the targets (be they citizens, healthcare workers or politicians) as heroes, i.e. those who have a crucial mission to accomplish for the welfare of society. This metaphor is strategically used by Johnson and Sánchez in different ways. For the British Prime Minister, the HERO metaphor, linguistically manifested in protect our NHS and save lives, projects a sense of solidarity: it is everyone's job to save lives. 


\section{Metaphors Used to Communicate the Coronavirus State of Emergency}

(15) Each and every one of us is now obliged to join together [...] to protect our NHS and to save many thousands of lives.

In the declaration delivered by the Spanish President, the HERO metaphor, however, is used differently. Here it performs a two-fold purpose: first, it is used as a way to praise healthcare professionals, employers and self-employed workers by virtue of the more specific metaphor Citizens are Heroes. Consider the following citation in which, as also seen in (4), Sánchez resorts to parallelism for emphasis:

(16) A los profesionales de la salud que sois ejemplo de heroicidad con vuestra entrega y vuestro trabajo, gracias. [...] A los empresarios y autónomos que sacrificáis los ingresos de vuestros negocios para proteger a vuestros clientes y trabajadores, gracias.

(To healthcare professionals, who are an example of heroism with your dedication and hard work, thank you [...]. To employers and self-employed workers, who sacrifice the income from your companies to protect your customers and your employees, thank you).

And second, it is employed as a strategy of positive self-presentation for Sánchez and the members of his government, who are heroically presented as people who are trying hard to protect the citizens from the virus (17) and save lives (18). In this case, the HERO metaphor can be specifically formulated as POLITICIANS ARE HEROEs; hence the prevailing function of metaphor as a device to shape belief in the public and political sphere.

(17) Nuestra misión y determinación [...] es máxima: proteger a los españoles.

(Our mission and determination [...] is maximum: to protect Spaniards).

(18) Cuantas más vidas nos ahorremos [...] más rotunda será esa victoria.

(The more lives we save [...], the greater the victory will be).

In any case, what seems evident is that the British and Spanish leaders resort to the HERO metaphor, first and foremost, for the comfort it provides: it pictures citizens and politicians as heroes who carry the burden of the pandemic and are working hard to overcome it.

\subsection{The JOURneY Metaphor}

As Lakoff argued, "complex events in general are also understood in terms of a source-path-goal schema: complex events have initial states (source), a sequence of intermediate stages (path) and a final stage (destination)" (1987: 275). This schema is used to frame the coronavirus crisis in terms of physical movement from one place to another in a metaphor that we can formulate as RECOVERY IS A JOURNEY. This metaphor is derived from a more general metaphor, LIFE IS A JOURNEY which, 


\section{Eliecer Crespo-Fernández}

in turn, can be considered a specification of a more abstract, superordinate metaphor, the EVENT STRUCTURE metaphor (Lakoff 1993) whereby events in general, including changes of states or activities, are conceptualised in terms of physical movement. Following Grady (1999), RECOVERY IS A JOURNEY is based on the primary metaphor PURPOSES ARE DESTINATIONS which associates purposes and destinations on the grounds of experiential correlation: moving towards one's destination is achieving a kind of goal in life. That goal, in the context of our corpus, is recovering from the coronavirus.

The main meaning focus of the JOURNEY metaphor (the idea of progress, of succeeding in reaching a goal in the journey towards a destination) is key to understanding the communicative force of the metaphor in Sanchez's declaration: the notion of progress serves his purpose to instil courage in the population. Like many leaders before him, for instance Tony Blair or Bill Clinton (see CharterisBlack 2005), Sánchez emphasises the notion of forward movement in the direction of one's goals. This forward movement, which becomes explicit in saldremos adelante (19) and avanzaremos ('we will move forward') (20), implies a positive change from one state to another, leaving the crisis behind and embracing a better future. Also of significance is the fact that the JOURNEY metaphor evokes the notion of being supported by travelling companions (note the use of the first person plural) who are supposed to be of help in the struggle against the virus:

(19) Que no quepa duda alguna: unidos, saldremos adelante.

(Let there be no doubt: united, we will move forward).

(20) Cuando por fin todo pase $[\ldots]$, avanzaremos.

(When everything finally passes $[\ldots]$, we will move forward).

Sánchez also uses a variation of the JOURNEY metaphor: the SAILING metaphor, which appears in the expression no perder el rumbo ('not to lose course') in (21). This phrase points to the need to work together on the way to recovery by focusing on the desired course of a ship during a voyage: the ship losing course would result in failure to reach the destination and could even affect the safety of the crew. The analogy between losing course and failure to recover from the disease is evident.

(21) No derrochemos energías que son precisas ahora. No perdamos el rumbo.

(Let us not waste energy that is necessary now. Let us not lose course)

However, in Johnson's declaration it is not the notion of movement, progress and direction that comes to the fore; rather, the path itself stands for the process of recovering from the disease by virtue of an entailment of the JOURNEY metaphor that Lakoff (1993) formulated as MEANS (OF CHANGE OF STATE/ACTION) ARE PATHS 


\section{Metaphors Used to Communicate the Coronavirus State of Emergency}

(TO DESTINATIONS). The MEANS ARE PATHS metaphor equates the social and sanitary measures taken to stop the spread of the disease with a path which leads to recovery as the end-point of the journey. It is therefore a path of hope.

It is interesting to mention that Johnson's use of the JOURNEY metaphor is not as optimistic as Sánchez's; in fact, the British Prime Minister admits that the travellers, i.e. citizens, are likely to meet obstacles along the way: the way abead is hard illustrates Lakoff's DIFFICULTIES ARE IMPEDIMENTS TO MOTION whereby the path to a destination is fraught with obstacles and challenges that delay or impede movement (1993: 220). In spite of this, in the British declaration, the JOURNEY metaphor is also used to instil confidence: the conviction that "there is a clear way through" suggests that the objective, i.e. final recovery, is seen as attainable with effort and determination:

(22) The way ahead is hard [...]. And yet it is also true that there is a clear way through.

As seen in the examples included in this section, the application of the source-pathgoal image schema is different in each subcorpus. Whereas in the Spanish one, it is the motion and the direction that comes to the fore, rather than the path (which is left implicit), in the British one the path is highlighted to offer some sort of hope. This provides evidence for the fact that the metaphorical use of the source domain is always partial (Ruiz de Mendoza Ibáñez and Pérez Hernández 2011: 66) and therefore subjective: some components of the source domain are activated in the comprehension of the target (movement from one place to another, direction or path in the examples seen in this section), while other aspects are disregarded. Indeed, the fact that journeys, especially cruises, are pleasurable activities is not mapped onto the target in any of the occurrences of the JOURNEY metaphor found in the corpus. In any case, what seems evident is that, as Charteris-Black argues, the JOURNEY metaphor functions as a tool that aids in transmitting a positive evaluation of political actors in so far as it assumes that reaching your destination is your goal and, obviously enough, "achieving goals is inherently good" (2004: 95).

\subsection{Other Metaphors}

Let us finally consider the metaphors that are less frequent in both subcorpora, namely CONTROL IS UP and THE CORONAVIRUS IS A NATURAL PHENOMENON (cf. Figure l). As stated earlier, the first two metaphors appear in both declarations, whereas the latter is only found in Johnson's.

Verbs such as rise and its equivalent in Spanish, levantarse, are cases of orientational metaphors that involve a spatial up-down relationship. More precisely, these terms are characterised by an upward orientation which is directly related with a positive evaluation (Kövecses 2005): they are instantiations of the primary metaphor 
CONTROL IS UP, which is grounded in our physical experience: being in control is being above. As Lakoff and Johnson put it, when we are in a vertical orientation "it is easier to control another person or exert force on an object from above" (1999: 53). Following Kövecses (2013), this metaphor is based on a metonymic relationship: our folk understanding of control constitutes a single domain, or frame, in which the element of being physically upward-oriented stands for control. From this perspective, CONTROL IS UP may be described as UP FOR CONTROL, as an element of the frame is used for the whole frame. ${ }^{10}$

This metaphor is used by both political leaders to instil courage in the population by suggesting that citizens, including the government itself, will take control of the crisis despite the difficulties of the moment:

(23) The people of this country will rise to that challenge.

(24) España tiene la capacidad de levantarse cuantas veces haga falta.

(Spain has the capacity to rise as many times as necessary).

I will finally look at another metaphor based on an analogical resemblance between source and target that, although of little relevance in absolute terms, is worthy of analysis as a fear-instilling description of COVID-19: THE CORONAVIRUS IS A (DANGEROUS) NATURAL PHENOMENON. The metaphors that evoke natural phenomena base their persuasive capacity on the association between the target domain (coronavirus in our case) and a potentially dangerous and wild nature as source domain. In (25) the coronavirus is represented as a tide, a term related to an excessive flow of water (cf. Charteris-Black 2005: 570-572; Semino 2008: 89-96). This analogy provides the raw material for warning the citizens about the danger of the pandemic, conceived as a dangerous natural phenomenon and a threat to national security. Indeed, the notions of DESTRUCTIVENESS and IRRATIONALITY, the main meaning foci of NATURAL PHENOMENA metaphors, apply in the following example in which the representation of coronavirus as a dangerous natural phenomenon combines with the view of the disease as a killer (see 4.2):

(25) We are buying millions of testing kits that will enable us to turn the tide on this invisible killer.

As happens with PHYSICAL FORCE metaphors (Crespo-Fernández 2015: 109-114), the notion of passivity features heavily in NATURAL PHENOMENA metaphors by implicitly suggesting that people are vulnerable and harmless at the mercy of natural forces. In (25), however, Johnson leaves the door open to optimism: he describes himself and the members of his government as active agents in the fight for health recovery. Again, the use of metaphor as a strategy of positive selfpresentation comes into play. 


\section{Concluding Remarks}

The analysis of the use of metaphor in the declarations of the state of emergency in Britain and Spain has revealed that metaphor serves a three-fold purpose: first, to instil courage in the population; second, to warn citizens about the danger of the pandemic; and third, to justify the measures taken by the government and thus avoid criticism from public opinion as part of a strategy of positive selfpresentation.

Evidence from the corpus indicates that the metaphors used by both Prime Ministers are similar: they show a preference for WARFARE metaphors in which recovery is conceptualised as a battle against an enemy. The source domains of PERSON, HERO and JOURNEY are also frequently used to refer to a range of issues, namely the coronavirus, the nation-state, the recovery process, the citizens and the political legislators. Although the set of conceptual metaphors is similar in both subcorpora, there are some differences: first, there is a considerably higher density of metaphor use in the British declaration; and second, the way the source domains are exploited differ in significant ways: Sánchez tries to sound more convincing by using those metaphors from the domains of WAR (victory) or JOURNeY (move forward) that best suit his persuasive needs. Furthermore, for Sánchez the HERO metaphor is part of a strategy of positive self-presentation, whereas for Johnson it tends to project a sense of solidarity and common goals.

The analysis also demonstrates that metaphors have an affective value and evaluative content. For example, metaphors with positive connotations such as THE STATE IS A PERSON, RECOVERY IS A JOURNEY and CONTROL IS UP are used to instil courage in the face of the coronavirus pandemic, similarly to what occurred with Churchill's wartime speeches (Crespo-Fernández 2013), in which the spoken word acts as a useful tool not only to inform, but also (and perhaps more importantly) to bolster morale in difficult times. For its part, the HeRo metaphor implies a positive evaluation of political actors which ultimately contributes to maintaining and legitimising political power (Crespo-Fernández 2018). From this point of view, metaphor operates as a useful strategy of self-protection and positive self-presentation. By contrast, the affective import of metaphors which conceptualise the virus as an enemy or a tide is negative: such metaphors basically serve the purpose of warning citizens about the danger of infection and thus persuading them into conforming to the law and staying at home. Like former political orators such as Margaret Thatcher or George Bush (Charteris-Black 2005), Johnson and Sánchez resort to negative metaphors of aggression to speak to the public. 


\section{Eliecer Crespo-Fernández}

In general, the findings of the present research seem to confirm those reported in studies published in the last decade regarding the role of metaphor when addressing infectious disease outbreaks. For instance, Trčková (2015) and Balteiro (2017), in journalistic and scientific texts respectively, demonstrated that WAR metaphors - mostly intended to empower patients and thus instil courage in citizens - are commonly used to talk about Ebola (which is represented as an enemy) and those involved in dealing with it (who are portrayed as fighters). Similarly, Wicke and Bolognesi (2020) and Fernández-Pedemonte et al. (2020) demonstrated that warrelated metaphors are commonly used to frame the discourse around COVID-19 on Twitter and in the headlines of Argentinian digital newspapers, respectively. Craig (2020) showed the prevalence of military metaphors in the journalistic discourse around what he calls the "coronavirus war", in which those workers deemed essential are portrayed as people serving on the frontline.

However, some of the results of previous studies on metaphors for COVID-19 differ from my findings here. For instance, Semino (2021) demonstrated that FIRE metaphors are used creatively in online news articles for different purposes, not only to convey the danger and threat posed by the coronavirus, but also to highlight the role of healthcare workers, who are depicted as firefighters. She also shows that SPORTS metaphors position the virus as the opponent and emphasise the need for patience and effort. Wicke and Bolognesi (2020) demonstrated that the virus is represented as a monster in Twitter posts, which frames the discourse about the behavior of COVID-19 in emotionally negative terms. For their part, Pérez-Sobrino et al. (in press) provide evidence that the metaphor of the hedgehog, which clearly contrasts with war-related metaphors, encourages the self-limiting behaviour that is necessary to reduce the spread of the virus. Furthermore, some of the metaphors analysed in this study are used differently in other contexts. As shown by Semino (2021), JOURNEY metaphors suggest a long and difficult process with an uncertain outcome, and metaphors involving severe weather or natural disasters, such as STORM and TSUNAMI metaphors (cf. Wicke and Bolognesi 2020), not only focus on the consequences of the virus, but also background the role of the governments responsible for financing health care systems.

Additional research into the metaphors used to describe the coronavirus crisis could consider whether metaphor use varies depending on political ideology and how it contributes to legitimising particular interests and practices to deal with the coronavirus. From a more general perspective, further studies devoted to the metaphors used by Johnson and Sánchez after their initial declarations of the state of emergency considered here could shed greater light on the role of figurative language in the rhetoric of both leaders. Furthermore, it would be interesting to ascertain whether the metaphors used in the public declarations analysed here are 
either metaphors Johnson and Sanchez use in talks or speeches on other topics - and are thus intrinsic to their personal style - or whether they are common in some political circles. For the sake of comparison, it would also be of value to investigate the style of a sample of other talks by the same Prime Ministers outside the pandemic context.

In summary, the analysis of metaphor use in the British and Spanish declarations of the state of emergency supports the view that metaphor is a double-edged sword in times of crisis: it is not only used to help people to face the coronavirus pandemic, it also serves as a strategy of positive self-presentation whereby political actors try hard to avoid criticism and gain approval for their decisions.

\section{Notes}

1. In order to understand the explanatory potential and limits of the early cognitive approach to metaphor with examples taken from political language, see Musolff (2012). For more recent developments and applications of contemporary metaphor theory in metaphor research, see Ruiz de Mendoza Ibáñez and Pérez Hernández (2011) and the volume edited by Gonzálvez-García et al. (2013).

2. In developing taxonomies of metaphor types, metaphors have been classified according to the nature of the source domain, the level of genericity of the domains involved in the mapping, the degree of complexity of the metaphoric operation, and the nature of the mapping system. For a comprehensive classification of metaphor types, see Ruiz de Mendoza Ibáñez and Pérez Hernández (2011: 167-180).

3. The question of metaphor deliberateness has sparked controversy. Gibbs (2011), for example, claims that deliberate metaphors are not essentially different from other forms of metaphorical language, whereas van Poppel (2020) argues that metaphors may actually be deliberate, depending on the context in which they are used. Concerning the distinction between metaphors that may be created deliberately and those that arise automatically, see Gibbs (2011, 2015), Steen (2015, 2017) and van Poppel (2020).
4. Unlike structural and ontological metaphors, orientational metaphors do not involve domains but concepts. This is why VERTICALITY is not a source domain but a concept.

5. Ureña and Faber (2010) propose a more refined description of resemblance metaphors. They claim that Grady's (1999) image metaphors (based on physical properties, e.g. shape and colour) and resemblance metaphors (based on behavioural comparison) are closely related: they both belong to a graded category based on the dynamicity of the mental images underlying them.

6. Italics added for emphasis in the examples from the corpus.

7. However, as Balteiro (2017: 213) notes, the use of metaphors for the portrayal of diseases and illnesses has not been exempt from criticism. For example, Sontag (1978) claimed that metaphors contribute to emphasising the negative consequences of illnesses on patients; more specifically, she argues that warfare metaphors tend to stigmatise certain patients and illnesses. In this respect, it is worth mentioning that the negative impact and pervasiveness of war language has recently given rise to the project \#reframeCovid, an initiative aimed at collecting and promoting alternatives to WAR 


\section{Eliecer Crespo-Fernández}

metaphors for the coronavirus pandemic (see https://sites.google.com/view/reframecovid/ initiative).

8. As Casado Velarde (2019) argues, to speak about "the others" is a discursive strategy that politicians employ to build the identity of the political opponent. He demonstrates that Podemos, a left-wing Spanish political party with a clear populist profile, represents "the others" as corrupt, unfair and despotic.

9. A high-level metonymy is a particular model of metonymy in which both source and target domains are generic cognitive models (Ruiz de Mendoza Ibáñez and Mairal Usón 2007). A double metonymy is a metonymic model that is further developed into a high-level action scenario (Ruiz de Mendoza Ibáñez and Díez Velasco 2002; Ruiz de Mendoza Ibáñez and Mairal Usón 2007).

10. Barcelona argues that all conceptual metaphors have some metonymic motivation. In his own words, "every metaphorical mapping presupposes a conceptually prior metonymic mapping, or to put it differently, [...] the seeds for any metaphorical transfer are to be found in a metonymic projection" (2003a: 31). For discussion on the interaction between metaphor and metonymy, see the volume edited by Barcelona (2003b).

\section{Works Cited}

Anderson, Wendy and John Corbett. 2017. Exploring English with Online Corpora. London: Palgrave.

BAIDER, Fabienne and Monika Kopytowska. 2017. "Conceptualising the Other: Online Discourses on the Current Refugee Crisis in Cyprus and Poland". Lodz Papers in Pragmatics 13 (2): 203-233. DOI: 10.1515/lpp-2017-0011

Balteiro, Isabel. 2017. "Metaphor in Ebola's Popularized Scientific Discourse". Ibérica 34: 209-230.

Barcelona, Antonio. 2003a. "On the Plausibility of Claiming a Metonymic Motivation for Conceptual Metaphor". In Barcelona, Antonio (ed.) Metaphor and Metonymy at the Crossroads: A Cognitive Perspective. Berlin: Mouton de Gruyter: 31-58.

Barcelona, Antonio. (ed.) 2003b. Metaphor and Metonymy at the Crossroads: A Cognitive Perspective. Berlin: Mouton de Gruyter.

Caballero, Rosario and Iraide IbarRetxe-Antuñano. 2009. "Ways of Perceiving and Thinking: Revindicating Culture in Conceptual Metaphor Research". Cognitive Semiotics 5 (1-2): 268-290.

Casado Velarde, Manuel. 2019. "El discurso político de Podemos: la construcción de una identidad". Círculo de Lingüística Aplicada a la Comunicación 80: 177-190. DOI: 10.5209/ CLAC.66606

Charteris-Black, Jonathan. 2004. Corpus Approaches to Critical Metaphor Analysis. Basingstoke:Palgrave.DOI: 10.1057/9780230000612

ChARTERIS-BLACK, Jonathan. 2005. Politicians and Rhetoric. The Persuasive Power of Metaphor. Basingstoke: Palgrave.

Charteris-Black, Jonathan. 2012. "Forensic Deliberations on Purposeful Metaphor". Metaphor and the Social World 2 (1): 1-21. DOI: 10.1075/msw.2.1.01cha

CHARTERIS-BLACK, Jonathan. 2014. Analysing Political Speeches. Basingstoke: Palgrave.

Chilton, Paul and George Lakoff. (1995) 2005. "Foreign Policy by Metaphor". In Schäffner, Christina and Anita Wenden (eds.) Language and Peace. Asdershot: Dartmouth: 37-59.

Cralg, David. 2020. "Pandemic and its Metaphors: Sontag Revisited in the COVID-19 Era". European Journal of Cultural Studies 23 (6): 1025-1032. DOI: 10.1177/1367549420938403

Crespo-Fernández, Eliecer. 2013. “Words as Weapons for Mass Persuasion: Dysphemism 


\section{Metaphors Used to Communicate the Coronavirus State of Emergency}

in Churchill's Wartime Speeches". Text \& Talk 33 (3): 311-330. DOI: 10.1515/text-2013-0014

Crespo-Fernández, Eliecer. 2015. Sex in Language. Euphemistic and Dysphemistic Metaphors in Internet Forums. London: Bloomsbury.

Crespo-Fernández, Eliecer. 2018. “Euphemism as a Discursive Strategy in US Local and State Politics". Journal of Language and Politics 17 (6): 789-811. DOI: 10/1075/jlp.17040.cre

FalRclough, Norman. 1989. Language and Power. London: Longman.

Fernández-Pedemonte, Damián, Felicitas Casillo and Ana Jorge-Artigau. 2020. "Communicating COVID-19: Metaphors We 'Survive' By". Tripodos 2 (47): 145-160.

Ferrari, Federica. 2007. "Metaphor at Work in the Analysis of Political Discourse: Investigating a Preventive War Persuasion Strategy". Discourse \& Society 18 (5): 603-625. DOI: $10.1177 / 0957926507079737$

GisBS, Raymond W. 2011. "Are 'Deliberate' Metaphors Really Deliberate? A Question of Human Consciousness and Action". Metaphor and the Social World 1 (1): 26-52. DOI: 10.1075/ msw.1.1.03gib

GiBBS, Raymond W. 2015. “Do Pragmatic Signals Affect Conventional Metaphor Understanding? A Failed Test of Deliberate Metaphor Theory". Journal of Pragmatics 90: 77-87. DOI: 10.1016/jpragma.2015.05.021

Gonzálvez-García, Francisco, María Sandra Peña Cervel and Lorena Pérez Hernández. (eds.) 2013. Metaphor and Metonymy Revisited beyond the Contemporary Theory of Metaphor. Recent Developments and Applications. Amsterdam: John Benjamins.

Grady, Joseph. 1999. “A Typology of Motivation for Conceptual Metaphor: Correlation vs. Resemblance". In Gibbs, Raymond and Gerard Steen (eds.) Metaphor in Cognitive Linguistics. Amsterdam: John Benjamins: 79-100.

Hughes, Geoffrey. 1998. Words in Time. A Social History of English Vocabulary. Oxford: Blackwell.

Karlberg, Michael and Leslie Buell. 2005. “Deconstructing the 'War of All against All':
The Prevalence and Implications of War Metaphors and other Adversarial News Schema in TIME, Newsweek, and Maclean's". Journal of Peace and Conflict Studies 12 (1): 22-39.

Kinsella, Elaine, Eric Igou and Timothy Ritchie. 2019. "Heroism and the Pursuit of a Meaningful Life". Journal of Humanistic Psychology 59 (4): 474-498. DOI: 10.1177/0022167817701002

Kövecses, Zoltán. 2005. Metaphor in Culture. Universality and Variation. Cambridge: Cambridge U.P.

KöVECSES, Zoltán. 2013. “The MetaphorMetonymy Relationship: Correlation Metaphors Are Based on Metonymy". Metaphor and Symbo/28(2):75-88. DOI: 10.1080/10926488.2013. 768498

LAKOFF, George. 1987. "The Death of Dead Metaphor". Metaphor and Symbolic Activity 2: 143-147.

LAKOFF, George. 1993. "The Contemporary Theory of Metaphor". In Ortony, Andrew (ed.) Metaphor and Thought. Cambridge: Cambridge U.P.: 202-251.

LAKOFF, George. 1995. “Metaphor, Morality, and Politics or Why Conservatives Have Left Liberals in the Dust". Social Research 69 (2): 177-213.

LAKOFF, George and Mark JoHnson. 1999. Philosophy in the Flesh: The Embodied Mind and its Challenge to Western Thought. New York: Basic Books.

LAKoff, George and Mark Turner. 1989. More than Cool Reason. A Field Guide to Poetic Metaphor. Chicago: The University of Chicago Press.

MusolfF, Andreas. 2012. "The Study of Metaphor as Part of Critical Discourse Analysis". Critical Discourse Studies 9 (3): 301331. DOI: $10.1080 / 17405904.2012 .688300$

Musolff, Andreas. 2016. Political Metaphor Analysis: Discourse and Scenarios. London: Bloomsbury.

Negro, Isabel. 2011. “Metaphor and Ideology in the Business Press: The Case of the Endesa Takeover". Miscelánea: A Journal of English and American Studies 43: 73-85. 


\section{Eliecer Crespo-Fernández}

Pérez-Sobrino, Paula, Elena Semino, Iraide IBARRETXE-ANTUÑANo, Veronika Koller and Inés OlzA (in press). "Acting Like a Hedgehog in Times of Pandemic: Metaphorical Creativity in the \#ReframeCovid Collection". Metaphor and Symbol.

Pragglejaz Group. 2007. "MIP: A Method for Identifying Metaphorically Used Words in Discourse". Metaphor and Symbol 22 (1): 1-39. DOI: 10.1080/10926480709336752

Ruiz de Mendoza Ibáñez, Francisco J. 1997. "Cognitive and Pragmatic Aspects of Metonymy". Cuadernos de Filología Inglesa 6 (2): 161-178.

Ruiz de Mendoza Ibáñez, Francisco J. 2021. "Conceptual Metonymy Theory Revisited: Some Definitional and Taxonomic Issues". In Wen, Xu and John R. Taylor (eds.) The Routledge Handbook of Cognitive Linguistics. New York: Routledge: 204-227.

Ruiz de Mendoza IbÁÑez, Francisco J. and Olga Díez Velasco. 2002. "Patterns of Conceptual Interaction". In Dirven, René and Ralf Pörings (eds.) Metaphor and Metonymy in Comparison and Contrast. Berlin: Mouton de Gruyter: 489532.

Ruiz de Mendoza Ibáñez, Francisco J. and Ricardo MAIRAL UsóN. 2007. "High-Level Metaphor and Metonymy in Meaning Construction". In Radden, Günter, Peter Siemund, Klaus Köpcke and Thomas Berg (eds.) Aspects of Meaning Construction. Amsterdam: John Benjamins: 33-51.

Ruiz de Mendoza IbÁñez, Francisco J. and Lorena Pérez Hernández. 2011. "The Contemporary Theory of Metaphor. Myths, Developments and Challenges". Metaphor \& Symbol 26 (3): 161-185. DOI: 10.1080/10926488.2011.583189

Semino, Elena. 2008. Metaphor in Discourse. Cambridge: Cambridge U.P.

Semino, Elena. 2021. "Not Soldiers but Firefighters. Metaphors and Covid-19". Health
Communication 36 (1): 50-58. DOI: 10.1080/ 10410236.2020.1844989

SonTAG, Susan. 1978. IIIness as Metaphor. New York: Farrar, Straus and Giroud.

Steen, Gerard. 2011. "The Contemporary Theory of Metaphor. Now New and Improved". Review of Cognitive Linguistics 9 (1): 26-64. DOI: $10.1075 / \mathrm{rcl} .9 .1 .03 \mathrm{ste}$

SteEn, Gerard. 2015. “Developing, Testing and Interpreting Deliberate Metaphor Theory". Journal of Pragmatics 90: 67-72. DOI: 10.1016/j. pragma.2015.03.013

SteEN, Gerard. 2017. “Deliberate Metaphor Theory: Basic Assumptions, Main Tenets, Urgent Issues". Intercultural Pragmatics 14 (1): 1-24. DOI: 10.1515/ip-2017-0001

TRČKovÁ, Dita. 2015. "Representations of Ebola and its Victims in Liberal American Newspapers". Topics in Linguistics 16: 29-41. DOI: 10.2478/topling-2015-0009

UreñA, José M. and Pamela FABER. 2010. "Reviewing Imagery in Resemblance and Non-Resemblance Metaphors". Cognitive Linguistics 21 (1): 123-149. DOI: 10.1515/cogl. 2010.004

VAN DIJK, Teun A. 2005. Racism and Discourse in Spain and Latin America. Amsterdam: John Benjamins.

VAN Poppel, Lotte. 2020. “The Relevance of Metaphor in Argumentation. Uniting Pragmadialects and Deliberate Metaphor Theory". Journal of Pragmatics 170: 245-252. DOI: 10.1016/j.pragma.2020.09.007

WiCKE, Philip and Marianna Bolognesı. 2020. "Framing COVID-19: How we Conceptualize and Discuss the Pandemic on Twitter". PLoS ONE 15 (9): e0240010. DOI: 10.1371/journal. pone. 0240010 